the much longer $4^{\text {th }}$ antennal segment, and the quite large marginal spines. None of these similar species have been found in the U. S.

\section{A JAPANESE COCCID QUARAN- TINED AT SAN FRANCISCO.}

Leucaspis japonicus, n. sp. - $q$ Scales numerous on the twigs, pyriform, about the form of Mytilaspis pomorum, but somewhat smaller, whitish with a strong greyishochreous tinge, exactly the color of the twig on which they rest; exuviae strongly contrasting, dark chestnut color. The second skin is large and narrow, only slightly overlapped by the first.

olongate, after boiling in soda pale orange-yellow; four well-developed lobes, similar in form, but the second smaller than the first, all about as far apart as the breadth of a median lobe, trilobed, the median lobule largest, the others very distinct and somewhat spreading. The wide areas between the median lobes, and between the first and second, are each occupied by a pair of deeply bifid plates, which do not extend to the level of the ends of the lobes. The margin cephalad of the second lobe is gently crenate, the low broad elevations resulting, about seven in number, being armed with three or more minute spinules, really rudimentary plates. Surface of hind portion conspicuously striate, anal orifice a long distance from hind end, no groups of ventral glands, but numerous large transversely elongate scattered glands. The whole lateral margin of the abdominal portion of the insect presents a thickened striate edge, with broad serrate chaff-like scales at very frequent intervals.

Hab. -- On broom from Japan, found Dec., I896, by Mr. Alex. Craw in the course of his horticultural quarantine work at San Francisco.

Note. - Since the above was written, Prof. Gillette has found the Lecanium flaveolum at the Colorado College. The proper name of the plant, according to Mr. Cowen, is Pilea microphyllum. - T. D. A. C., March 2.

\title{
THE LARVAL STAGES OF ARCTIA ANNA GROTE.
}

\section{BY HARRISON G. DYAR, NEW YORK, N. Y.}

Eggs were obtained from a female moth of the persephone form at Greenwood Lake, N. J., in June.

Egg. Neatly conoidal, the base flat and concave; pale yellowish white, shining; the reticulations very fine, broad, not sharp, rounded, the areas between forming shallow indistinctly margined pits; height, $.6 \mathrm{~mm}$., diameter $.9 \mathrm{~mm}$.

Stage I. Head bilobed, the lobes dark blackish brown, clypeus pale, whitish; width $.4 \mathrm{~mm}$. Cervical shield narrow, dusky; body whitish, with long, stiff, dark setae; warts pale; later both warts and leg-plates shining dusky gray, large. Setae normal, the subprimaries absent, but wart iii on the abdomen bears two hairs, including the large subdorsal wart on joint 13 which has four hairs. At the end of the stage the appearance is whitish, the segments faintly brown dotted, not distinctly banded, the warts dusky, not contrasting.

Stage II. Head bilobed, the lobes shining blackish, clypeus pale; width $.55 \mathrm{~mm}$. Body whitish, shaded with red-brown around the dusky warts, giving the appearance of longitudinal bands, especially a pale dorsal line. Warts hairy, normal, large except $i$ which is very small and vi which is moderate. Hairs stiff, black, a few longer ones posteriorly from the subdorsal wart on joint 13 . After eating, the body becomes sordid greenish, the larva consequently appearing dark.

Stage III. Head shining black, the cly- 
peus pale yellowish; width $\cdot 7 \mathrm{~mm}$. Body thick and robust with large black warts, grayish, brown mottled, no marks except a faint, pale, dorsal line. Hair abundant, stiff, bristly, barbuled coarsely, black, a few longer hairs posteriorly. Later there is a faint wavy white subdorsal line below wart ii.

Stage IV. Lobes of head shining black, clypeus pale yellowish; width I.I mm. Body blackish brown, not so dark as usual, no marks except a very faint paler straight dorsal and a lateral line (below ii). Warts shining black, faintly pale ringed at the base. Hair as before with the addition of two very long slender white hairs from joint 13. Later the pale marks around warts iii are faintly reddish.

Stage $V$. Head pale brownish, a black shade on each lobe in front, mouth brown, eyes large, black; width $1.55 \mathrm{~mm}$. Body black, the warts shining, large with stiff black hairs, a pair of long ( $2 \mathrm{~mm}$.) white ones posteriorly. No distinct marks; a faint whitish dash below wart iii, fine pale dorsal and subdorsal (below ii) lines; lateral area paler than the dorsal, the bases of warts iii to $\mathrm{v}$ slightly reddish.

Stage VI. Head shining black, bases of antennae and line above mouth whitish; width $2.2 \mathrm{~mm}$. Body all black, velvety; warts shining, the bases of ii to iv faintly reddish under a lens, no marks visible to the unaided eye. Hair bristly, deep black, barbuled, some longer ones posteriorly, but all alike black. Tips of feet pale.

Stage VII (interpolated). Head black, the sides, clypeus, sutures and mouth more brownish; width 2.5 to $2.7 \mathrm{~mm}$. Body black, the basal rings of the warts dull luteous, warts shining, no other marks. Hair very coarse with barbules as before.

Stage VIII. Head as in stage vi, width about $3 \mathrm{~mm}$. Body and hair black, the bases of the warts shining, the ends of all the feet pale; no marks. The back and sides of the head are brownish and later the antennae and line above the mouth becomes pinkish.
The larvae hibernate in this stage. The growth is slow. The eggs hatched toward the end of June, the last molt took place between August 24th and September 12 th in different larvae and hibernation began soon afterward.

Food plants various low plants.

\section{PINK LOCUSTARIANS.}

A SPECimen of Amblycorypha oblongifolia of a vinous color was sent me in 1886 by Mrs. Sidney I. Smith who took it Aug. 9, at Wood's' Holl. It was dead when it reached me but had been kept alive some time. All the green parts including both tegmina and wings were tinted of a uniform color except that the thickened green flecks of the normal tegmina and the lateral carinae of the pronotum were fuscous. So too were the eyes, but the antennae, except the extreme base, were luteous like the ordinary form. The specimen was a $q$ and the color extended to the ovipositor of course, the denticles of which were fuliginous.

Two other specimens ( $\delta$ q) of the same species were also taken at the same place by Mr. Richard Rathbun and Prof. A. E. Verrill on Aug. 29, 1886, and were examined while still living. The $q$ is of a pale coral red verging on magenta, the abdomen a shade paler, while the $\delta$ is of an orange red. The tegmina of the $q$ are of a very clear color with scarcely a single fleck of brown while those of the $\delta$ are much dotted (for Amblycorypha) with brown and longitudinally flecked with yellow, while the stridulating field is almost entirely dull brown, and an obscure patch of the same color more distinct on one side than the other appears near the middle of the outer half of the tegmina near the upper margin. In both the palpi are of the color of the body, but the eyes are green and the antennae of the normal luteous. The lateral carinae of the pronotum are luteous in the $q$, fuscous in the $\delta$. 

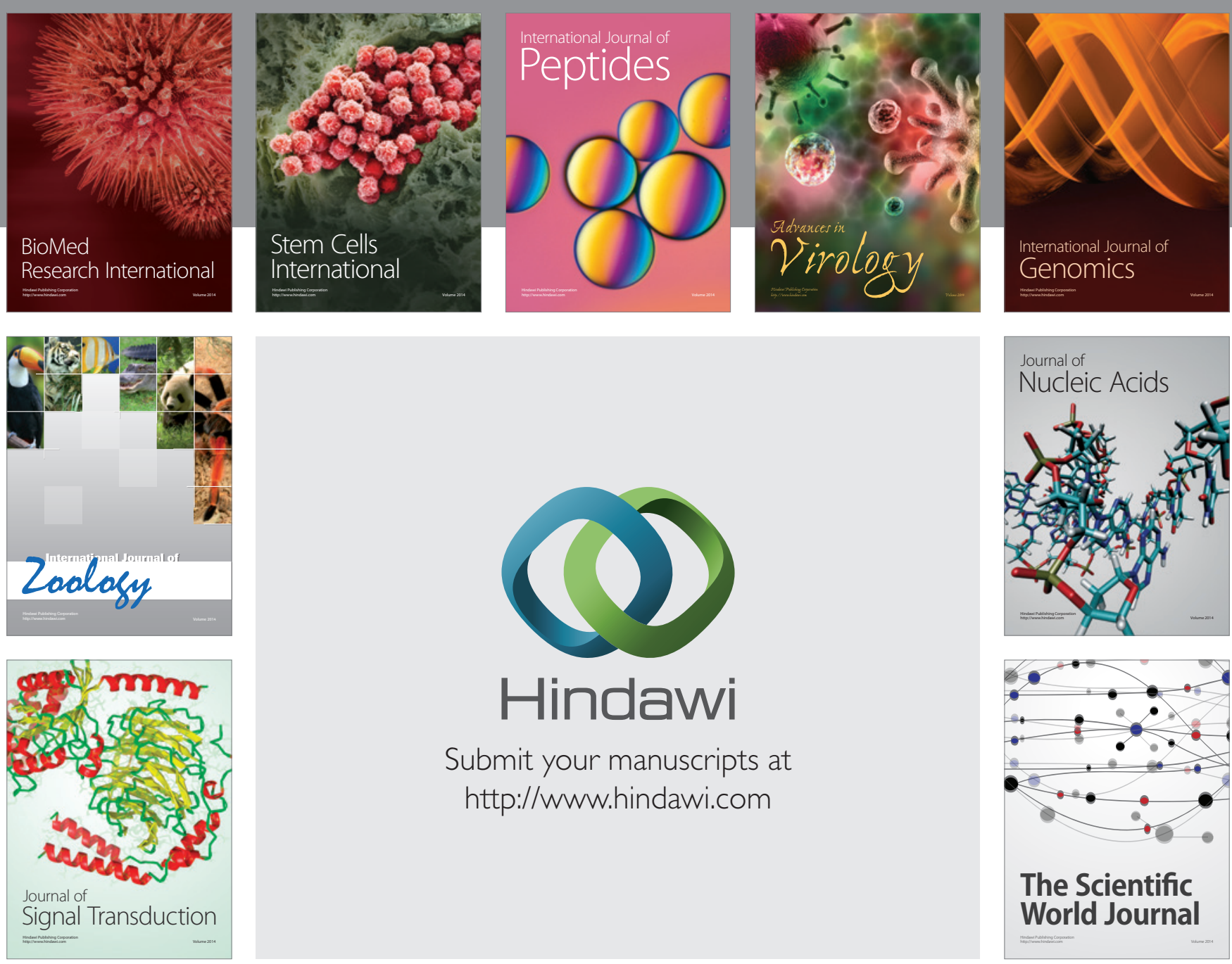

Submit your manuscripts at

http://www.hindawi.com
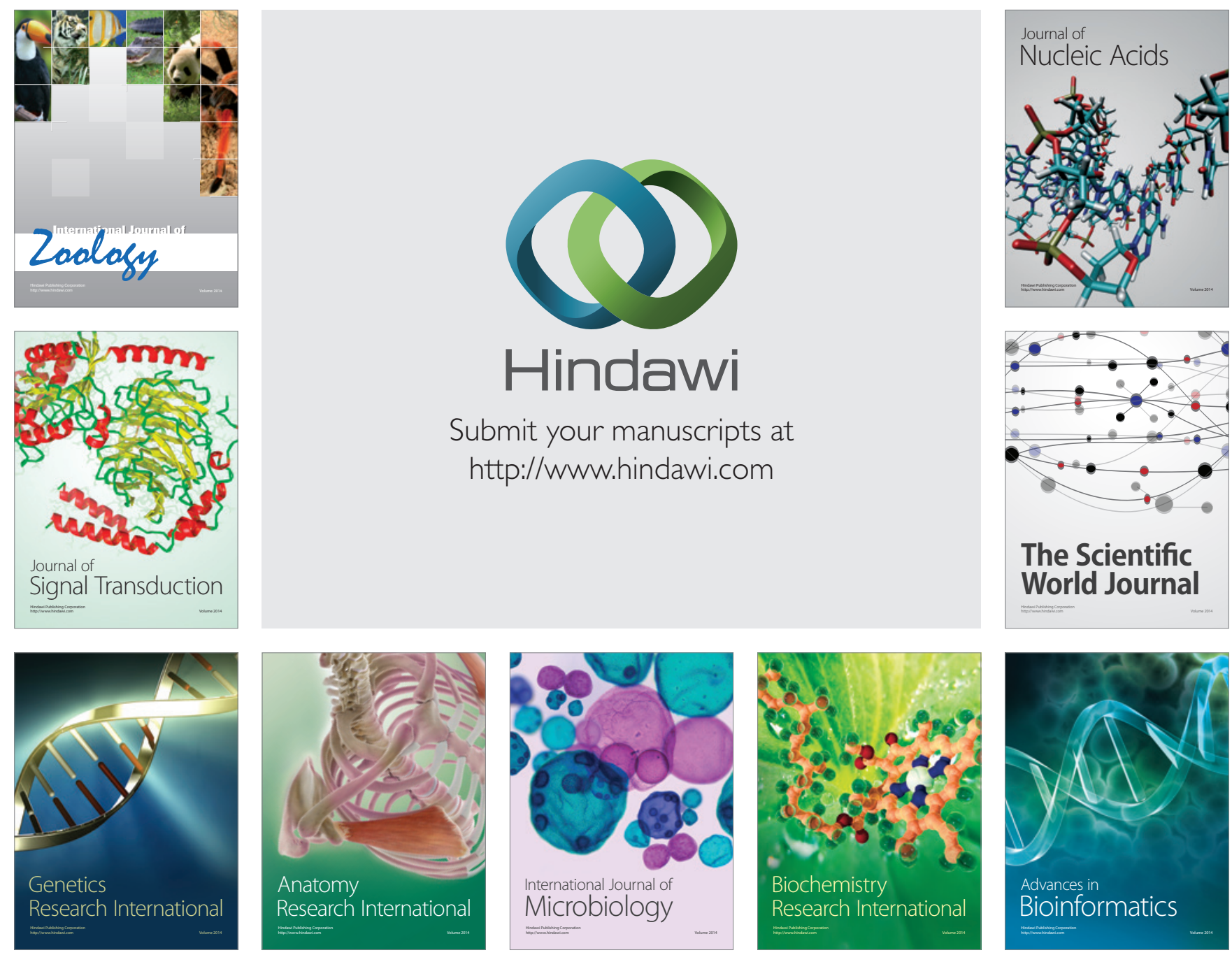

The Scientific World Journal
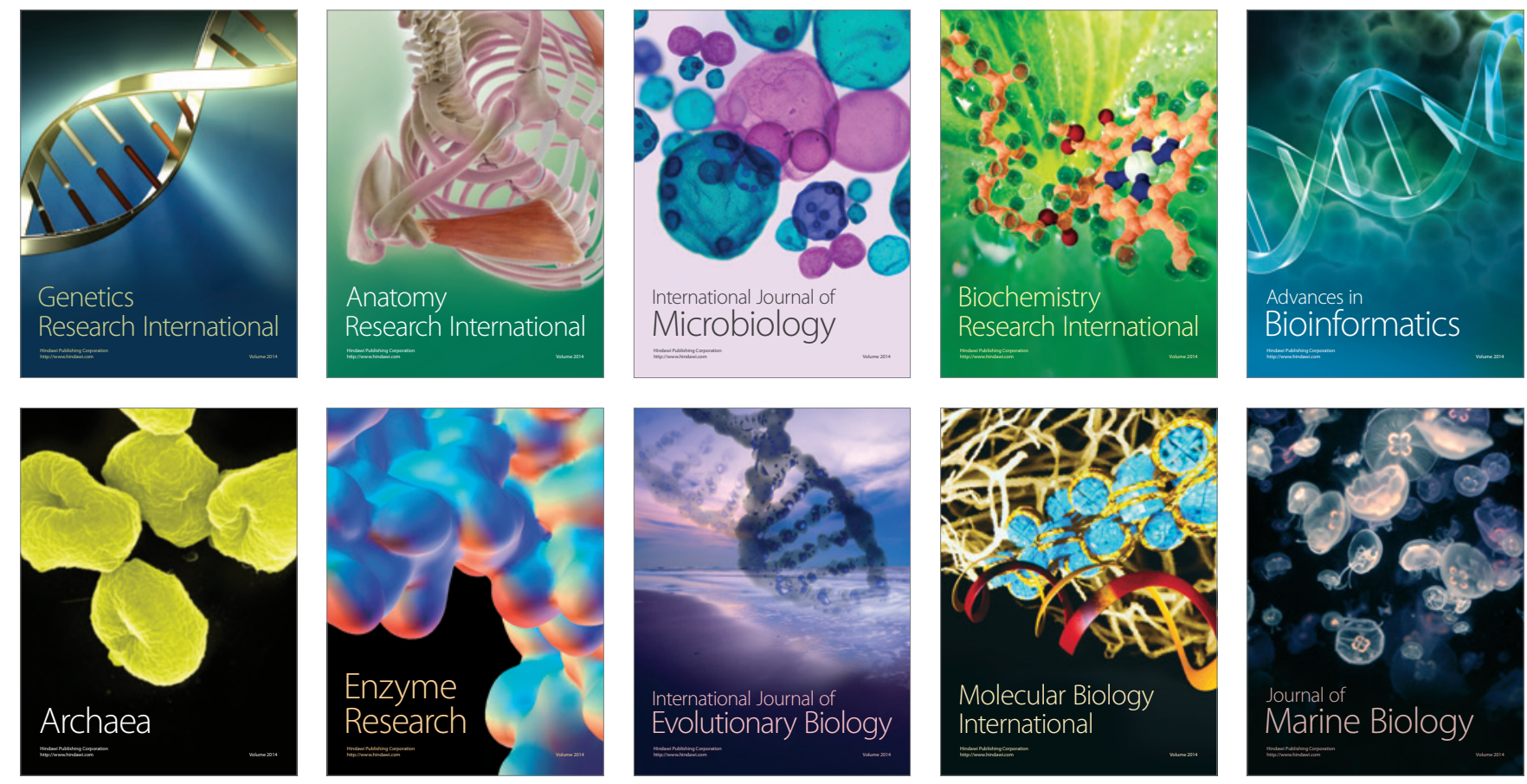